\title{
Rationality in Education: to the question of the content component of an Academic discipline
}

\author{
O. Dolska, V. Lobas \\ Department of Philosophy, National Technical University "Kharkiv Polytechnic Institute"
}

Paper received 19.05.21; Accepted for publication 12.06.21.

\author{
https://doi.org/10.31174/SEND-HS2021-253IX45-17
}

\begin{abstract}
Today, many countries are experiencing a crisis in education, which they are trying to cope with in various ways. One of the dominant elements of possible reforming is a change in the content of the academic discipline. Attempts to revise or transform it directly or indirectly concern the topic of pedagogical reason and rationality in education. The authors suggest taking into account the levels of rationality in education when constructing the content component. The options in the nature of changes in the content component have always indicated not only new educational strategies, but also a paradigm shift in education.
\end{abstract}

Keywords: rationality, education, the content component of the academic discipline, the paradigm of education.

Introduction. The topic of rationality has always been the focus of philosophy. It has been described and analyzed for two millennia, offering various options for understanding it. In our opinion, it is advisable to consider rationality in education ambiguously. The first thing that needs to be emphasized is that rationality in education appears in the form of human-creative potential, and it is education that demonstrates this side of it in practice. Another definition of rationality is associated with thinking: rationality is a movement of thought that presupposes the existence of norms and rules that determine the standards of thinking in the form of objectified human experience. Rationality in this understanding is considered by us as a technique of thinking. Finally, we actualize the modern understanding of rationality, namely, as a way of human activity.

Relevance and literature review. The problem of rationality in education must be considered in the context of the theory of education, the potential of which is contained in the studies of T. Parsons, M. Weber, N. Luhmann, J. Habermas and others. They record the transition from the 'internal' effectiveness of the educational system to the 'external' one, which is determined by its relationship with all systems of society and the lifeworld.

Purpose: Based on the social essence of the content of education, the content component can be defined as a pedagogical model of social order.

Main part. We associate the presence of formal and substantive levels of rationality with the concept of objective and subjective reason. This concept is analyzed by M. Horkheimer in his work Critique of Instrumental Reason. He considers objective reason as independent of subjective reason and at the same time as a special force inherent in interpersonal relations, relations between social institutions, social institutions and nature. Subjective reason, devoid of openness to the objective meanings of reason, is deprived of any objective strength. Even the correct work of thinking on the example of making inferences with the preservation of all formal requirements does not give the objective strength of the content, does not provide a universal vector for condemning its content. Subjective reason, devoid of objectivity, loses "what makes up its subjectivity" [1, p. 60] and turns into a formalized mind, with which spiritual intellectual processes are in no way connected.

The system of scientific knowledge, discoveries of a technical and technological nature, the cultural experience of mankind, the emotional and imaginative world of art, historical traditions, the system of activity, value orientations, etc. are components of educational content. In the legislative documents on the education of any country, one of the priority directions is an update of the content of education and the forms of organization of the educational process. The current state of the education system requires greater attention to updating the content of many disciplines, which is associated with many factors. The issue of the content component has always been the focus of scientists' attention. A significant contribution to the development of the education content was made by such Ukrainian scientists as: L. Gorbunova, I. Dobronravova, M. S. Klepko, M. Kultayeva, O. Tyaglo, L. Kiyashchenko, M. Boychenko, O. Gomilko, S. Kurbatov, S. Proleyev, N. Kochubei and others. This topic was also directly and indirectly touched upon by such Polish philosophers as T. Kotarbinsky, B. Trentovskiy, $\mathrm{K}$. Tvardovsky and others. The issue of the curricula content, the forms of knowledge transfer is in the focus of attention of the English representatives of the philosophy of education among who there are H. Daniels and H. Lauder, Sir Ken Robinson, who led a national commission on creativity, education and the economy for the UK Government advising on the development of creative thinking, education systems and innovations in government and public organizations, and Finnish philosiphers and educators (P.Sahlberg). The relevance of the problem of the substantive component of academic disciplines is evidenced by the research of Ukrainian scientists: O.M. Donik, O.P. Leshchinskyi, N.L. Sosnitskaya and others.

The guiding principle in constructing the content of education is the principle of scientific character. T. S. Kuhn in his work The Structure of Scientific Revolutions wrote about the difficulties of transforming scientific knowledge into objective knowledge and gave examples confirming this. One example is the origin of the notion of 'chemical element', which is attributed to R. Boyle. He proposed it in order to prove that no chemical elements exist. The textbook version of his contribution is wrong in terms of history. But such an error is accepted over time, and then they introduce it into the working structure of the educational text. "Verbal definitions like Boyle's have little scientific content when considered by themselves. They are not full logical specifications of meaning (if there are such), but more nearly pedagogic aids. .... Both Boyle and Lavoisier changed the chemical significance of 'element' in important ways. But they did not invent the notion or even change the verbal formula that serves as its definition"'[8, p. 142].

G. Bachelard also wrote about the difficulties of operating 
with theoretical notions, and R. Rorty, discussing the problem of interpretations, believed that "pedagogical knowledge largely depends on the teacher's interpretation of scientific knowledge and the formation of rule systems that are contained in scientific theory" [5]. The content component of pedagogical knowledge is based on scientific knowledge, but "is formed as some transformation of the ideal objects of the discipline" [2, p. 119] in order to simplify the ever-increasing potential of the complexity of scientific knowledge. To sum up, we can say that the most difficult part of constructing the content of education is the problem of the selection of scientific knowledge for various subject cycles.

The social aspect and the demands/challenges of the time are of great importance for the formation of the content component. The social essence of the content of education is determined by the fact that, together with the learning process, it serves as the main means of transferring social experience to the younger generation. At the same time, the content of education does not copy the social order, but interprets it, reveals and concretizes it by means of its discipline, personal pedagogical skills, realizing it in personal perceptions and practices. One of the main factors that must be taken into account when designing the education content is the needs of society and the goals it sets for education. These needs and goals are largely determined by a different understanding of reason because the content of education cannot be outside the sphere of rational control. Teaching each discipline/subject can have a large number of goals and objectives which indicates a multifaceted palette of pedagogical activity and creates space for senses of teaching, and each has a certain logical line of its implementation. Hence there is a possibility of coexistence of certain schools, directions, possible methods. The choice of one of them by a teacher is determined by their value attitude, culture, ability to interpret cultural senses in relation to modern value series, traditions.

The choice of a certain meaning and logic of presentation is largely determined by the time factor. If we analyze the problems of the content component of the end of the 20th century and the beginning of the 21 st century, we can see that the trajectories of transformations go in different ways. For example, in the 1980s the physics curriculum was influenced by several factors. The content component of physics can direct towards the formation of engineering thinking, namely, the ability to design some mechanisms, devices based on physical knowledge. The second line can be the development of model thinking, where the ability to create models of a symbolic nature is formed. However, in the late 1980s, public opinion in the United States addressed the issues of the environmental problems caused by the development of science and technology. As a result, new physics courses, containing a new content component, and courses aimed at increasing the technological literacy of students appear. Practical problems were presented in a generalized form as problems of transport, energy, storage, and transmission of information. These courses were aimed at the formation of a special kind of communicative relations, namely between the artificial world and the natural world, at the problems of a communicative nature within the artificial world itself, and, finally, at the formation of a person's communicative attitude to these worlds.

And since the mid-1990s changes affected the university course in general physics. The American Association of Engineers has decided that a general physics course is optional for the professional training of engineers. Instead, specific knowledge and skills are needed in the physics course [4, p. 22]. Mathematics can also be taught in completely different contexts, with different content. For example, as M. Kline notes, there are several approaches to setting out its foundations. Among them are "set-theoretic, logistic, axiomatic, intuitionistic" [3, p. 116]. The choice of one of the logics of presentation is largely determined by historical and cultural factors and a teacher's personal position.

In the 21 st century, the construction and design of the content component of any subject take on new shades, the special value of which is determined by new challenges. Teaching the discipline "Philosophy", for example, focuses on developing critical thinking and the ability to give their opinion of events and processes. Therefore, problem fields of a thematic nature most often become the content component as follows: the search for problems, their articulation, discussion, critical reflection, the creation of problem narratives, etc. things. [7].

Analyzing the work of the Finnish education system and thinking of it as an outstanding phenomenon, renowned teachers and scholars talk about several factors that contributed to this. And each of them highlights one of the factors that is teachers' independency when it goes to curriculum designing. "Finnish teachers are completely autonomous in designing their own work plans and curricula... The work of a Finnish teacher with a Master's degree is based not only on existing scientific knowledge but also on the ability to plan, conduct educational research and analyze their results to gain new knowledge and develop new teaching methods for further professional development" [10, p. 276].

It should be noted that in the 21 st century, non-institutional education providers have a huge influence. It is a surprising phenomenon that these structures also actively address a content component pursuing certain goals. To exemplify, we want to draw attention to the design of educational programs of today's phenomenon - yoga. Yoga is a multifaceted system, close to the esoteric one, where the work of the spirit, physical body, psychosomatic components is a single whole. It is a philosophy of the ancients, reinforced by modern medical knowledge, transformed into a socio-cultural training of a post-secularized society. The content components of teaching modern yoga are diverse: the training, the manner of presenting knowledge depend on many factors. There are schools where sports loads and poses are the only content component - we are talking about body practices (postural yoga). Such schools focus on physical training, power exercises, complexes of breathing and flexibility exercises, stress relief, strengthening and cleansing of the body, the search for ideal physical shape of the body, etc. There are also other schools, the content components of which are determined by the central figures (gurus), deities, symbolic images (animals):

"Scientific literacy, epistemological relativism, pseudoscience and what constitutes 'valid knowledge' are some of the most common topics of discussion. Based on my own observations in yoga studios and in online forums, the most common deities found in yoga studios are: Siva-natarāja (the dancer), Kṛ̣na (the flute player), Hanumāna (the monkey) and Ganeśa (the elephant). Interestingly, Buddha is also quite popular. One respondent believes that this is because Buddha statues are easier to get and possibly less confronting than some Hindu statues. Another popular approach includes 
honouring one's lineage with life-size photos of gurus, like the 'pioneers' of modern yoga, such as T. Krishnamacharya, B.K.S. Iyengar, Pattabhi Jois, and T.K.V. Desikachar. These are hung on the walls in yoga studios "[9].

There are other meaningful components that are used to introduce other accents, and sometimes the whole philosophy of learning changes. For example, the Asanga Yoga school is based on traditional yoga schools. Asanga is a Sanskrit compound consisting of the terms $a$ and sanga (सड्ग) and indicates the impossibility of attachment to anything [6, p. 1, 95]. The name came from the Sanskrit word 'Asanga' (असङ्ग) - "non-attachment, not being attached to, not sticking to anything" $[6$, p. 1, 95]. The term emphasizes the task of forming a person's detachment from the profane in order to achieve the transcendent. Therefore, the school program includes not only physical exercises but also intellectual work on shaping a worldview. The content component of this school is based on four main directions of yoga, the roots of which are found in the original ancient texts. It includes not only postural yoga (body poses), but also introduces students to the content of the texts of such ancient books as Bhagavad Gita, Patanjali's Yoga Sutras, Hathapradipika, excerpts from the Upanishads. Such a meaningful component helps to create the basis for possible metaphysical reflexions, transcendental transitions and states of thought, and at the same time forms a special attitude to culture and society.

The various content components of yoga schools are associated with numerous interpretations of yoga that is partly due to limited access to its original sources or unwillingness to spend time on theoretical processing of knowledge. This explains a very narrow concept of what yoga really is. Of course, the texts do not explain or give a single definition of yoga, but they provide views on it from different cultural contexts and activate the chronological aspect, which makes paradigmatic analysis and understanding of yoga possible.

The large-scale positioning of the secularized narrative contributed to the spiritual crisis of modernity, in which the dialectic of the 'spiritual-corporeal' and 'social-spiritual' oppositions sharpened. When studying ancient texts, the basic tenets and conceptual things of yoga are analyzed, their assimilation and 'binding' to the challenges of modernity are shown. The use of the content component, constructed on the basis of knowledge of ancient texts, not only activates the interest in the culture of the body, it unfolds new worldview horizons before a modern man. Its goal is to harmonize the traditional components of world integrity: spirit - body - space - nature.

Conclusions. Formal and substantive levels of rationality allow us to pay attention to, on the one hand, such components in didactics as techniques and technologies of thinking, on the other hand, setting education goals and forming both institutionalized and non-institutionalized education providers. The meeting of paradigms of education is a clash not only of their metaphysical components but also of value orientations of different pedagogical directions, schools.

The content component can act as an option that is mandatory for all students to learn: it is imposed by state educational standards, regulations. However, today we also need variants of the content component, which are tied to the target settings, the task of which is to expand the horizontalvertical scale of knowledge in order to create interdisciplinary complexes, projects to deepen narrowly oriented approaches in education. Finally, they can be tailored to specific or inclusive audiences. Based on the social essence of the content of education, the content component can be defined as a pedagogical model of social order. As the development of society is gaining a digital character, the possibilities of shaping and designing the content component expand essentially at the expense of technological and technical innovations. Information technologies with their inexhaustible capabilities provide completely unexpected solutions in the formation of the content component, which emphasizes its status as a mobile complex of knowledge.

\section{LITERATURE}

1. Горкгаймер М. (2006). Критика інструментального розуму. Київ: ППС.

2. Имакаев, В. Р. (2007). Герменевтический подход к построению содержания образования, Философские науки, 5, 115136.

3. Клайн, М. (1984). Математика. Утрата определенности. Москва: Мир.

4. Ліщинський, О. М. (2005). Розвиток змісту шкільного курсу фізики у Великій Британії, Німеччині та США (XIX - XX ст.): автореф. дис. на здобуття вчен. ступеню докт. педагог. наук. Київ, 41.

5. Рорти, Р. (2000). Философия и зеркало культуры In: Постмодерн в философии, науке, культуре. Харьков: СиМ, 159-194.

6. Benfey, T. (1866). A Sanskrit-English dictionary: with references to the best editions of Sanskrit authors and etymologies and com-

parisons of cognate words chiefly in Greek, Latin, Gothic, and Anglo-Saxon. London, Longmans, Green, and Co.

7. Karivets, I. (2018). Problem-based teaching of philosophy (On the example of the National University «Lviv Polytechnic»). Philosophy of Education, 1 (22), 180-199.

8. Kuhn, Th. S. (1970). The Structure of Scientific Revolutions. Second Edition, Enlarged. The USA, The University of Chicago, Volumes I\&II.

9. McCartney, P. (2017). Politics beyond the Yoga Mat: Yoga Fundamentalism and the 'Vedic Way of Life'. Journal Global Ethnographic, May, 2017, Issue 4. URL: https://oicd.net/ge/wpcontent/uploads/Politics-byond-the-Yoga-Mat-P.-

McCartney.pdf.

10. Pomogaibo, V. (2018). Philosophy of Successful Finnish Education (review of Passy Salberg's book «Finnish Lessons 2.0»). Philosophy of Education. 2 (23), 270-282.

\section{REFERENCES}

1. Gorkgaymer M. (2006). Kritika Instrumentalnogo rozumu. KiYiv: PPS.

2. Imakaev, V. R. (2007). Germenevticheskiy podhod k postroeniyu soderzhaniya obrazovaniya, Filosofskie nauki, 5, 115

3. Klayn, M. (1984). Matematika. Utrata opredelennosti. Moskva: Mir.

4. Lishchynskyi, O. M. (2005). Rozvytok zmistu shkilnoho kursu fizyky u Velykii Brytanii, Nimechchyni ta SShA (KhIKh - KhKh st.): avtoref. dys. na zdobuttia vchen. stupeniu dokt. pedahoh. nauk. Kyiv, 41.

5. Rorty, R. (2000). Fylosofyia y zerkalo kulturb In: Postmodern v fylosofyy, nauke, kulture. Kharkov: SyM, 159-194. 